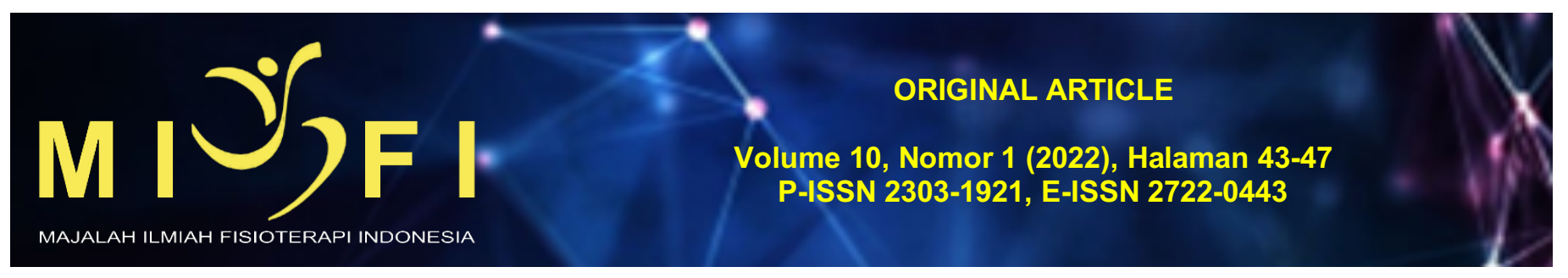

\title{
KOMBINASI PELATIHAN ABDOMINAL STRETCHING EXERCISE DAN CORE STRENGTHENING EXERCISE DAPAT MENURUNKAN NYERI DISMENORE PRIMER PADA MAHASISWI FISIOTERAPI FAKULTAS KEDOKTERAN UNIVERSITAS UDAYANA
}

\author{
Kadek Nindia Dwi Pratiwi Putri ${ }^{1}$, Ni Luh Nopi Andayani², I Putu Adiartha Griadhi ${ }^{3}$, \\ Luh Made Indah Sri Handari Adiputra ${ }^{4}$
}

\author{
${ }^{1}$ Program Studi Sarjana Fisioterapi dan Profesi Fisioterapi, Fakultas Kedokteran Universitas Udayana, Denpasar, Bali \\ ${ }^{2}$ Departemen Fisioterapi, Fakultas Kedokteran Universitas Udayana, Denpasar, Bali \\ ${ }^{3,4}$ Departemen Ilmu Faal, Fakultas Kedokteran Universitas Udayana, Denpasar, Bali \\ *Koresponden: nindiapratiwi27@gmail.com
}

Diajukan: 25 Juni 2021 | Diterima: 28 Juni 2021 | Diterbitkan: 25 Januari 2022 DOI: https://doi.org/10.24843/MIFI.2022.v10.i01.p09

\begin{abstract}
ABSTRAK
Pendahuluan: Dismenore primer merupakan nyeri ketika menstruasi yang terjadi tanpa adanya gangguan patologis. Secara non farmakologis, latihan fisik adalah salah satu cara dalam mengurangi nyeri dismenore. Latihan fisik berupa kombinasi abdominal stretching exercise dan core strengthening exercise yang diberikan selama 12 minggu dinyatakan efektif dalam menurunkan nyeri dismenore primer. Namun belum di ketahui pengaruh kombinasi kedua latihan ini dalam jangka waktu yang lebih singkat yaitu antara siklus menstruasi awal ke menstruasi berikutnya. Adapun tujuan dari penelitian ini yaitu untuk mengetahui pengaruh kombinasi pelatihan abdominal stretching exercise dan core strengthening exercise yang diberikan selama 3 minggu terhadap penurunan nyeri dismenore primer pada mahasiswi Fisioterapi Fakultas Kedokteran Universitas Udayana.

Metode: Penelitian ini menggunakan metode pre-eksperimental dengan desain One Group Pre Test-Post Test Design. Subjek berjumlah 12 orang yang dipilih melalui cara purposive sampling. Data dikumpulkan melalui pengukuran intensitas nyeri dismenore primer dengan Numeric Rating Scale (NRS) sebelum dan setelah diberikan latihan.

Hasil: Berdasarkan uji analisis non parametrik Wilcoxon Signed Ranks Test didapatkan nilai $p=0,002(p<0,05)$.

Simpulan: Kombinasi pelatihan abdominal stretching exercise dan core strengthening exercise dapat menurunkan nyeri dismenore primer pada mahasiswi Fisioterapi Fakultas Kedokteran Universitas Udayana.
\end{abstract}

Kata Kunci: nyeri, dismenore primer, abdominal stretching exercise, core strengthening exercise, mahasiswi

\section{PENDAHULUAN}

Perempuan normal pada umumnya mengalami siklus reproduksi, dimana setiap bulan perempuan akan mengalami menstruasi. ${ }^{1}$ Menstruasi merupakan perdarahan uterus yang periodik dan siklik disertai dengan pengelupasan (dekuamasi) endometrium. ${ }^{2}$ Pengalaman menstruasi yang dirasakan pada setiap perempuan berbeda dan bervariasi. Pada beberapa perempuan, menstruasi yang dialami dapat disertai dengan keluhan, seperti mengalami rasa nyeri atau kram di sekitar perut bagian bawah ketika menstruasi. ${ }^{3}$ Nyeri yang terjadi ketika menstruasi disebut dengan dismenore. ${ }^{4}$ Terjadinya dismenore disebabkan oleh karena dinding rahim mengalami kontraksi yang lama dan kuat, tingginya hormon prostaglandin, dinding rahim yang melebar ketika mengeluarkan darah saat menstruasi, serta adanya kontraksi yang kuat pada miometrium ketika mengeluarkan darah haid, akibatnya terjadi ketegangan otot saat kontraksi dan timbulah nyeri. ${ }^{5}$

Dismenore dapat diklasfikasikan menjadi 2 jenis, yang terdiri atas dismenore primer dan dismenore sekunder. Dismenore primer merupakan dismenore yang timbul tidak disertai dengan gangguan patologis di organ reproduksi, sedangkan dismenore sekunder merupakan dismenore yang timbul disertai kelainan patologis di organ reproduksi. ${ }^{6}$ Faktor-faktor yang mempengaruhi terjadinya dismenore, yaitu tingkat stress, genetik, menarke usia dini, usia, indeks massa tubuh (IMT), aktivitas fisik, dan makanan. ${ }^{6,7}$ Di dunia, angka kejadian dismenore rata-rata hingga diatas $50 \%$. Di Amerika Serikat dinyatakan angka kejadian dismenore mencapai $60 \%$ dan di Swedia mencapai hingga $72 \% .{ }^{8} \mathrm{Di}$ Indonesia kejadian dismenore mencapai $64,25 \%$, dengan persentase dismenore primer $54,89 \%$ dan sisanya menderita dismenore sekunder. ${ }^{4}$ Umumnya, dismenore primer mencapai titik maksimal pada usia $15-25$ tahun. ${ }^{6}$

Dismenore dapat mengganggu aktivitas sehari-hari penderitanya, sehingga tidak dapat melakukan aktivitas dengan normal. ${ }^{1,4}$ Begitupula pada remaja yang mengalami dismenore akan menyebabkan aktivitas sehari-harinya terbatas, termasuk aktivitas belajarnya. ${ }^{4}$ Dismenore menyebabkan terganggunya aktivitas belajar, penurunan konsentrasi, bahkan hingga tidak bisa berkonsentrasi sama sekali dan keinginan untuk belajar juga akan menurun sehingga materi yang disampaikan ketika kegiatan belajar mengajar berlangsung tidak dapat diterima dengan baik. ${ }^{4,9}$ Nyeri akibat dismenore primer dapat dikurangi dengan berbagai cara, antara lain melalui pengobatan farmakologis dan non farmakologis. Dalam mengurangi dismenore secara non farmakologis dilakukan dengan latihan fisik. ${ }^{10}$ Ketika melakukan latihan fisik otak akan mengeluarkan hormon endorfin sehingga menimbulkan perasaan nyaman dan 
menenangkan secara alami. ${ }^{11}$ Salah satu jenis latihan fisik yang bisa diterapkan sebagai cara dalam menurunkan gejala nyeri pada dismenore primer yaitu abdominal stretching dan core strengthening exercise. .,10 $^{-0}$

Stretching abdominal merupakan bentuk latihan dengan meregangan otot-otot perut sehingga dapat menguatkan otot, meningkatkan fleksibilitas dan ketahanan otot. ${ }^{5}$ Penguatan core memiliki tujuan untuk menguatkan otot-otot yang mengelilingi lumbal. ${ }^{10}$ Kombinasi abdominal stretching exercise dan core strengthening exercise menyebabkan kapiler-kapiler darah pada otot mengalami vasodilatasi dan permeabilitasnya meningkat sehingga dapat meningkatkan metabolisme dan aliran darah ke uterus. Selain itu, ketika melakukan latihan fisik ini dapat menghasilkan $\beta$-endorfin. ${ }^{5,12} \beta$-endorfin merupakan analgesik non spesifik yang dapat menurunkan frekuensi dan tingkat keparahan nyeri dismenore. ${ }^{5}$

Berdasarkan penelitian terdahulu yang dilakukan oleh Purwitasari, et al (2021) menyatakan bahwa kombinasi abdominal stretching exercise dan core strengthening exercise yang diberikan selama 12 minggu dapat menurunkan intensitas nyeri dismenore primer. ${ }^{13}$ Namun belum di ketahui pengaruh kombinasi kedua latihan ini dalam jangka waktu yang lebih singkat yaitu antara siklus menstruasi awal ke menstruasi berikutnya. Oleh karena itu pada penelitian ini, peneliti bermaksud untuk melihat pengaruh kombinasi pelatihan abdominal stretching exercise dan core strengthening exercise yang diberikan selama 3 minggu dalam menurunkan nyeri dismenore primer pada mahasiswi Fisioterapi Fakultas Kedokteran Universitas Udayana.

\section{METODE}

Jenis penelitian ini yaitu pra-eksperimental dengan desain Pre Test-Post Test Design. Penelitian dilaksanakan bulan November 2020 hingga Maret 2021 yang dilaksanakan secara daring. Pada penelitian ini untuk menentukan jumlah subjek yang dibutuhkan menggunakan rumus pocock dan berdasarkan penelitian terdahulu oleh Rosyida, et al (2017) sehingga didapatkan jumlah sampel yaitu 12 orang. ${ }^{14}$ Power penelitian yang digunakan yaitu $80 \%$ atau tingkat kesalahan II sebesar $20 \%$. Subjek yang diambil pada penelitian ini yaitu merupakan mahasiswi Program Studi Sarjana Fisioterapi dan Profesi Fisioterapi yang mengalami nyeri dismenore primer berdasarkan kriteria inklusi dan kriteria eksklusi dengan cara pengambilan sampel berupa purposive sampling. Adapun kriteria inklusi tersebut terdiri dari mahasiswi Program Studi Sarjana Fisioterapi dan Profesi Fisioterapi Fakultas Kedokteran Universitas Udayana, berusia 18-21 tahun, bersedia berpartisipasi sebagai subjek dalam penelitian ini dengan menandatangani informed consent, tidak sedang melakukan latihan fisik secara rutin, tidak mengonsumsi obat-obatan pereda nyeri saat dismenore, dan mengalami gejala dismenore primer yang diketahui melalui pengisian kuesioner dismenore yang diadaptasi dari women's health questionnaire, menstrual history questionnaire, dan menstrual symptometrics dengan kriteria mengalami nyeri perut bawah sebelum atau di awal mulainya menstruasi, mengalami siklus mentruasi normal seperti menstruasi secara teratur dengan panjang siklus antara 21-35 hari dan lama menstruasi 3-7 hari. ${ }^{15}$ Kriteria eksklusi pada penelitian ini yaitu mempunyai riwayat menjalani pengobatan rutin, mempunyai riwayat cedera ataupun operasi pada abdomen, mempunyai riwayat nyeri perut bawah diluar siklus menstruasi, dan memiliki riwayat perdarahan di luar siklus menstruasi. Kriteria drop out dalam penelitian ini yaitu 3 kali berturut-turut tidak melakukan latihan dan subjek yang mengundurkan diri. Seluruh subjek menjadi 1 kelompok dan mendapatkan perlakuan yang sama.

Varibel dependen dalam penelitian ini yaitu intensitas nyeri dismenore primer, sedangkan variabel independen yaitu kombinasi abdominal stretching exercise dan core strengthening exercise. Dalam penelitian ini, digunakan NRS (Numeric Rating Scale) untuk mengetahui tingkat nyeri dismenore primer sebelum dan setelah diberikan perlakuan. Berdasarkan penelitian sebelumnya, belum terdapat laporan hasil nilai validitas dan reliabilitas NRS dalam mengukur nyeri pada populasi dismenore. Pengukuran dengan NRS dilakukan dengan cara menginstruksikan subjek untuk menyebutkan intensitas nyeri yang dialaminya dari skala $0-10$, dimana 0 artinya tidak ada nyeri, sedangkan 10 artinya nyeri yang sangat hebat. ${ }^{16,17}$ Latihan fisik berupa abdominal stretching exercise dan core strengthening exercise dilakukan secara mandiri oleh subjek setelah sebelumnya dilakukan pengajaran pelatihan melalui Webex oleh fisioterapis. Latihan dilakukan 3 kali perminggu selama 3 minggu dengan total sebanyak 9 sesi. Setiap sesi latihan dilakukan selama 15-20 menit.

Proses analisis data dilakukan menggunakan SPSS dengan analisis univariat untuk mengetahui usia, intensitas nyeri dismenore primer sebelum dan setelah diberikan latihan, uji normalitas menggunakan Shapiro-Wilk Test yang bertujuan agar dapat melihat distribusi data termasuk normal atau tidak normal dan uji hipotesis digunakan uji Wilcoxon Signed Ranks Test untuk menguji perbedaan hasil sebelum dan setelah perlakuan dengan tingkat signifikansi $p=0,05$. Penelitian ini dinyatakan laik etik oleh Komisi Etik Penelitian (KEP) Fakultas Kedokteran Universitas Udayana / Rumah Sakit Umum Pusat Sanglah Denpasar dengan No. 029/UN14.2.2.VII.14/LT/2020.

\section{HASIL}

Berikut ini dipaparkan deskripsi data penelitian yang mencakup karakteristik subjek penelitian dalam bentuk tabel. Berikut ini adalah deskripsi karakteristik subjek berdasarkan usia, intensitas nyeri dismenore primer sebelum dan setelah pelatihan.

Tabel 1. Distribusi Karakteristik Subjek berdasarkan Usia, Intensitas Nyeri Dismenore Sebelum dan Setelah Pelatihan

\begin{tabular}{lcc}
\hline Karakteristik & Frekuensi & Persentase \\
\hline Usia & & \\
18 & 4 & $33,30 \%$ \\
19 & 2 & $16,70 \%$ \\
20 & 2 & $16,70 \%$ \\
21 & 4 & $33,30 \%$ \\
\hline
\end{tabular}


Lanjutan Tabel 1. Distribusi Karakteristik Subjek berdasarkan Usia, Intensitas Nyeri Dismenore Sebelum dan Setelah Pelatihan

\begin{tabular}{ccc}
\hline Karakteristik & Frekuensi & Persentase \\
\hline Intensitas Nyeri Sebelum & Pelatihan \\
1 & 1 & $8,30 \%$ \\
2 & 1 & $8,30 \%$ \\
3 & 4 & $33,30 \%$ \\
4 & 2 & $16,70 \%$ \\
5 & 2 & $16,70 \%$ \\
6 & 2 & $16,70 \%$ \\
Intensitas Nyeri Setelah Pelatihan \\
0 & 3 & $25 \%$ \\
1 & 6 & $50 \%$ \\
2 & 3 & $25 \%$ \\
3 & 0 & $0 \%$ \\
4 & 0 & $0 \%$ \\
5 & 0 & $0 \%$ \\
6 & 0 & $0 \%$ \\
\hline
\end{tabular}

Berdasarkan Tabel 1. Didapatkan distribusi frekuensi subjek berdasarkan usia, intensitas nyeri sebelum dan setelah pelatihan. Karakteristik sampel berdasarkan usia memiliki rentang usia yaitu 18-21 tahun sesuai dengan kriteria inklusi, dimana mayoritas subjek berusia 18 tahun dan 21 tahun yaitu masing-masing berjumlah 4 orang (33,3\%). Karakteristik subjek berdasarkan intensitas nyeri sebelum pelatihan, subjek mayoritas mengalami nyeri dengan skala 3 sejumlah 4 orang $(33,3 \%)$ dari total subjek 12 orang. Berdasarkan karakteristik intensitas nyeri setelah pelatihan, subjek mayoritas mengalami nyeri dengan skala 1 yaitu sejumlah 6 orang (50\%) dari total subjek 12 orang. Intensitas nyeri subjek diukur menggunakan NRS.

Tabel 2. Uji Normalitas Shapiro-Wilk Test

\begin{tabular}{cc}
\hline Kelompok Data & $\mathrm{p}$ \\
\hline Intensitas nyeri sebelum pelatihan & 0,547 \\
Intensitas nyeri setelah pelatihan & 0,020 \\
\hline
\end{tabular}

Berdasarkan Tabel 2. menunjukkan hasil uji normalitas intensitas nyeri subjek sebelum pelatihan yaitu $p>0,05$ $(0,547)$ yang dapat diartikan bahwa intensitas nyeri subjek sebelum pelatihan berdistribusi normal, sedangkan intensitas nyeri subjek setelah pelatihan menunjukkan hasil $p<0,05(0,020)$ yang dapat diartikan bahwa intensitas nyeri subjek setelah pelatihan memiliki distribusi tidak normal. Berdasarkan hasil tersebut, maka dalam menguji hipotesis digunakan uji statistik non parametrik.

Tabel 3. Hasil Uji Wilcoxon Signed Ranks Test

\begin{tabular}{|c|c|c|c|}
\hline \multirow{2}{*}{ Kategori Data } & Sebelum Pelatihan & Sesudah Pelatihan & \multirow[b]{2}{*}{$p$} \\
\hline & Median \pm Interqua & artile Range (IQR) & \\
\hline Intensitas N & $3,50 \pm 2,00$ & $1,00 \pm 2,00$ & 0,002 \\
\hline
\end{tabular}

Dalam pengujian hipotesis digunakan uji statistik non parametrik, berupa Wilcoxon Signed Ranks Test untuk mengetahui perbedaan intensitas nyeri sebelum pelatihan dan setelah pelatihan. Berdasarkan hasil uji didapatkan $p<0,05(0,002)$, yang dapat diartikan bahwa terdapat perbedaan intensitas nyeri yang signifikan pada subjek sebelum dan setelah diberikan pelatihan. Berdasarkan Tabel 3. dapat dilihat nilai median intensitas nyeri sebelum pelatihan yaitu 3,50 dan setelah pelatihan yaitu 1,00. Hal ini berarti sebelum intervensi separuh subjek penelitian memiliki skor nyeri lebih besar dan lebih kecil dari 3,50. Sementara data setelah intervensi menunjukkan bahwa separuh subjek penelitian memiliki skor nyeri lebih besar dan lebih kecil dari 1,00.

\section{DISKUSI}

\section{Karakteristik Subjek Penelitian}

Penelitian ini berjalan selama 4 bulan yaitu akhir Bulan November 2020 hingga awal Bulan Maret 2021 secara daring. Pada penelitian ini mengambil subjek mahasiswi Program Studi Fisioterapi Fakultas Kedokteran Universitas Udayana sebanyak 12 orang mahasiswi yang mengalami nyeri dismenore primer berdasarkan kriteria inklusi dan eksklusi. Semua subjek diberikan latihan abdominal stretching exercise dan core strengthening exercise. Subjek dalam penelitian ini memiliki rentang usia 18-21 tahun yang termasuk dalam kategori remaja dengan mayoritas subjek berusia 18 tahun dan 21 tahun, dimana sebanyak 4 orang (33,3\%) berusia 18 tahun dan juga sebanyak 4 orang (33,3\%) berusia 21 tahun. Berdasarkan hasil penelitian, nyeri dismenore primer yang dialami subjek sebelum diberikan pelatihan memiliki median 3,50 dimana mayoritas subjek memiliki intensitas nyeri 3 yaitu sebanyak 4 orang (33,3\%). Sedangkan intensitas nyeri dismenore yang dialami subjek setelah diberikan pelatihan memiliki median 1 dengan mayoritas subjek memiliki intensitas nyeri 1 sebanyak 6 orang (50\%).

\section{Pengaruh Pemberian Pelatihan Kombinasi Abdominal Stretching Exercise dan Core Strengthening Exercise terhadap Penurunan Nyeri pada Kondisi Dismenore Primer}

Berdasarkan hasil uji statistik rata-rata intensitas nyeri subjek mengalami penurunan setelah diberikan latihan berupa abdominal stretching exercise dan core strengthening exercise selama 3 minggu. Hasil uji hipotesis dengan Wilcoxon Signed Ranks Test (Tabel 3.) pada intensitas nyeri sebelum dan setelah diberikan pelatihan ditemukan hasil 
$p=0,002(p<0,05)$ yang memiliki arti adanya penurunan yang signifikan pada intensitas nyeri subjek sebelum dan setelah diberikan pelatihan.

Hal serupa juga ditemukan pada hasil penelitian oleh Bustan, et al (2018) dengan 96 subjek yang dipisahkan menjadi 2 kelompok, yaitu kelompok perlakuan dan kontrol. Kelompok perlakuan mendapatkan latihan berupa abdominal stretching exercise dan kelompok kontrol tidak mendapatkan perlakuan, didapatkan hasil yaitu pada kelompok perlakuan terjadi penurunan nyeri yang signifikan setelah diberikan latihan selama 3 minggu. ${ }^{20}$ Begitupula pada hasil penelitian oleh Eittah dan Ashour (2017) yang menyatakan bahwa adanya pengaruh core strengthening exercise dalam menurunkan intensitas nyeri dismenore setelah diberikan latihan selama 8 minggu. ${ }^{21}$ Selain itu, penelitian sebelumnya yang dilakukan di Fakultas Kedokteran Universitas Udayana oleh Sutawinata \& Primayanti (2017) menyatakan bahwa terdapat hubungan yang signifikan antara olahraga aerobik yang sesuai anjuran dengan dismenore primer. Dalam penelitian tersebut dinyatakan bahwa dengan melakukan olahraga secara teratur, nyeri yang dialami ketika dismenore akan berkurang oleh karena meningkatnya suplai darah dan oksigen ke pembuluh darah yang mengalami vasokonstriksi serta pelepasan hormon endorfin sehingga ambang batas nyeri meningkat. ${ }^{22}$

Dismenore primer adalah nyeri yang dialami ketika menstruasi tanpa disertai oleh abnormalitas pada panggul. ${ }^{23}$ Biasanya nyeri yang dialami seperti nyeri kram dan berpusat pada perut bagian bawah. ${ }^{6}$ Dismenore primer biasanya dialami sebelum ataupun bersamaan dengan dimulainya menstruasi dan terjadi selama beberapa jam. ${ }^{23}$ Dismenore primer terjadi akibat adanya peningkatan kadar prostaglandin. ${ }^{5}$ Prostaglandin yang meningkat menimbulkan iskemia dan nyeri pada perut bagian bawah oleh karena terjadinya hipertonus dan vasokonstriksi pada myometrium. ${ }^{5,24}$

Secara non farmakologis nyeri pada kondisi dismenore primer dapat dikurangi dengan cara melakukan latihan fisik. ${ }^{10}$ Abdominal stretching exercise dan core strengthening exercise merupakan latihan fisik yang bisa diterapkan secara mandiri. Abdominal stretching exercise adalah suatu bentuk latihan dengan meregangkan otot perut yang berguna dalam menguatkan otot, meningkatkan fleksibilitas, dan ketahanan otot, sehingga nyeri menstruasi dapat berkurang. ${ }^{5}$ Core strengthening exercise adalah bentuk latihan untuk kontrol otot disekitar tulang belakang lumbal dengan tujuan menjaga stabilitas fungsional. Core strengthening dapat memperkuat otot-otot disekitar tulang belakang lumbal. ${ }^{10}$

Melakukan latihan fisik berupa abdominal stretching exercise dan core strengthening exercise dapat mengakibatkan kapiler-kapiler darah pada otot-ototnya mengalami vasodilatasi. ${ }^{12}$ Vasodilatasi oleh karena melakukan latihan fisik terjadi melalui proses nitrit oksida. ${ }^{25}$ Masuknya nitrit oksida dan menurunkan pemasukan kalsium ke otot polos mengakibatkan terjadinya vasodilatasi sehingga menyebabkan peningkatan metabolisme dan aliran darah ke jaringan yang mengalami iskemi. ${ }^{12,25}$ Selain itu, ketika melakukan abdominal stretching exercise dan core strengthening exercise juga dapat menstimulasi hormone $\beta$-endorfin. ${ }^{5,12}$ Neuron nyeri yang ada di perifer meneruskan sinyal ke sinaps, lalu neuron nyeri perifer bersinaps dengan neuron yang mengarah ke otak, ke tempat yang seharusnya impuls dihantarkan oleh substansi P. Lalu endorfin akan menghambat transmisi impuls nyeri pada medulla spinalis dengan memblokir pelepasan substansi $P$ dari neuron sensorik. ${ }^{5}$

Terjadinya vasodilatasi dan terstimulasinya hormon $\beta$-endorfin ketika melakukan latihan fisik berupa abdominal stretching exercise dan core strengthening exercise inilah yang menyebabkan terjadinya penurunan nyeri pada kondisi dismenore primer. ${ }^{5,12}$

\section{SIMPULAN}

Berdasarkan hasil penelitian terbukti bahwa kombinasi pelatihan abdominal stretching exercise dan core strengthening exercise dapat menurunkan nyeri dismenore primer pada mahasiswi Fisioterapi Fakultas Kedokteran Universitas Udayana.

\section{DAFTAR PUSTAKA}

1. Ningsih R, Setyowati S, Rahmah H. Efektivitas Paket Pereda Nyeri Pada Remaja Dengan Dismenore. J Keperawatan Indones. 2013 Jul 13;16(2):67-76.

2. Fajri A, Khairani M. Hubungan Antara Komunikasi Ibu-Anak Dengan Kesiapan Menghadapi Menstruasi Pertama (Menarche) pada Siswi SMP Muhammadiyah Banda Aceh. J Psikol Undip. 2011;10(2):133-43.

3. Sari D, Nurdin AE, Defrin. Hubungan Stres dengan Kejadian Dismenore Primer pada Mahasiswi Pendidikan Dokter Fakultas Kedokteran Universitas Andalas. J Kesehat Andalas. 2015;4(2):567-70.

4. Susanti RD, Utami NW, Lasri L. Hubungan Nyeri Haid (Dysmenorrhea) dengan Aktivitas Belajar pada Remaja Putri MTs Muhammadiyah 2 Malang. J IIm Keperawatan. 2018;3(1):144-52.

5. Syaiful Y, Naftalin SF. Abdominal Stretching Exercise Menurunkan Intensitas Dismenorea pada Remaja Putri. J Ilmu Kesehat. 2018;7(1):269-76.

6. Ammar UR. Faktor Risiko Dismenore Primer Pada Wanita Usia Subur di Kelurahan Ploso Kecamatan Tambaksari Surabaya. J Berk Epidemiol. 2016;4(1):37-49.

7. Indahwati AN, Muftiana E, Purwaningroom DL. Hubungan Mengonsumsi Makanan Cepat Saji (Fast Food) dengan Kejadian Dismenore Pada Remaja Putri di SMP N 1 Ponorogo. Indones J Heal Sci. 2017;1(2):7-13.

8. Gustini L, Lipoeto NI, Utama BI. Hubungan Massa Lemak dengan Dismenore Primer pada Remaja Putri di Stikes Ceria Buana Bukittinggi. J Kesehat Andalas. 2017;6(1):32-6.

9. Dawood MY. Primary Dysmenorrhea: Advances in Pathogenesis and Management. Obstet Gynecol. 2006;108(2):428-41.

10. Kaur S, Kaur $P$, Shanmugam S, Kang $M$. To compare the effect of stretching and core strengthening exercises on Primary Dysmenohrrea in Young females. IOSR J Dent Med Sci. 2014;13(6):22-32.

11. Sormin NM. Efektivitas Senam Dismenore dalam Mengurangi Dismenore pada Remaja Putri di SMP Negeri 2 Siantan Kabupaten Pontianak. J ProNers. 2014;2(1). 
12. Saleh SH, Mowafy HE, EIHameid AAA. Stretching or Core Strengthening Exercises for Managing Primary Dysmenorrhea. J Women Heal Care. 2016;5(1):1-6.

13. Purwitasari IA, Sundari LP, Lesmana I, Weta IW, Wihandani ID, Wulanyani IM. Perbandingan Kombinasi Abdominal Stretching dan Core Strengthening dengan Kombinasi Abdominal Stretching dan Pilates Exercise dalam Menurunkan Intensitas Nyeri Dismenore Primer. Sport Fit J. 2021;9(1):19-28.

14. Rosyida DAC, Suwandono A, Ariyanti I, Suhartono S, Mashoedi ID, Fatmasari D. Comparison of Effects of Abdominal Stretching Exercise and Cold Compress Therapy on Menstrual Pain Intensity in Teenage Girls. Belitung Nurs J. 2017;3(3):221-8.

15. Tristiana A. Hubungan aktivitas fisik dengan kejadian dismenore primer pada santri di pondok pesantren $\mathrm{X}$ di Kabupaten Bogor. 2019.

16. Merdekawati D, Dasuki D, Melany H. Perbandingan Validitas Skala Ukur Nyeri VAS dan NRS terhadap Penilaian Nyeri di IGD RSUD Raden Mattaher Jambi. Ris Inf Kesehat. 2019;7(2):114-21.

17. Maidartati M, Hayati S, Hasanah AP. Efektivitas Terapi Kompres Hangat terhadap Penurunan Nyeri Dismenore pada Remaja Di Bandung. J Keperawatan BSI. 2018;6(2):156-64.

18. Hidayah N, Rusnoto, Fatma I. Pengaruh Abdominal Stretching Exercise terhadap Penurunan Dismenore pada Siswa Remaja di Madrasahaliyah Hasyim Asy'Ari Bangsri Kabupaten Jepara. 5th Urecol Proceeding. 2017;95463.

19. Wahyunindita RN. Efektivitas Abdominal Stretching Exercise dalam Menurunkan Intensitas Nyeri Haid (Dismenore). J Kebidanan J Med Sci IImu Kesehat Akad Kebidanan Budi Mulia Palembang. 2019 Dec 4;9(2):142-6.

20. Bustan MN, Seweng A, Ernawati. Abdominal Stretching Exercise in Decreasing Pain of Dysmenorrhea among Nursing Students. J Phys. 2018;1028(1):1-6.

21. Eittah HFA, Ashour ESS. The Impact of Heat Application Versus Stretching and Core Strengthening Exercises on Relieving Pain of Primary Dysmenorrhea among Young Females. J Res Nurs Midwifery. 2017;6(3):47-55.

22. Sutawinata AA, Primayanti DAID. Hubungan Kebiasaan Olahraga Aerobik Terhadap Dismenore Primer pada Mahasiswi 18-24 Tahun Fakultas Kedokteran Universitas Udayana. E-Jurnal Med. 2017;6(12):127-30.

23. Madhubala C, Jyoti K. Relation between Dysmenorrhea and Body Mass Index in Adolescents with Rural versus Urban Variation. J Obstet Gynecol India. 2012;62(4):442-5.

24. Wulanda C, Luthfi A, Hidayat R. Efektifitas Senam Dismenore pada Pagi dan Sore Hari terhadap Penanganan Nyeri Haid pada Remaja Putri saat Haid di Smpn 2 Bangkinang Kota Tahun 2019. J Kesehat Tambusai. 2020;1(1):1-11.

25. Krestanaya I. Hubungan Frekuensi dan Intensitas Senam Aerobik dengan Derajat Dismenore pada Peserta Senam Aerobik di Kota Pontianak. J Mhs PSPD FK Univ Tanjungpura. 2015;3(1):1-21. 